\title{
Prevalence of antibiotic resistant enteric bacteria in the hands of street food vendors in Dhaka city
}

\author{
Md. Mahade Hassan ${ }^{1}$, Ram Prosad Chakrabarty ${ }^{1}$, Mohammad Anwar Siddique ${ }^{1}$, Md. Mizanur Rahaman ${ }^{1 *}$ \\ ${ }^{I}$ Department of Microbiology, University of Dhaka, Dhaka-1000, Bangladesh.
}

\begin{abstract}
Foodborne pathogens are affecting public health globally. Street foods being an important part in daily life of urban people are considered as a major source of foodborne pathogens. The major sources of street food contamination are water and the unhygienic condition of the vendors and food preparing places. This study was carried out to assess the load of antibiotic resistant enteric bacteria in the hands of street food vendors. A total of 20 street food vendors were selected from various locations in the Dhaka University campus and their hands were rinsed with $500 \mathrm{~mL}$ normal saline. Most of the samples contained high total viable counts, total coliforms count and total fecal coliforms count. A total of 25 selective colonies were identified as enteric bacteria including $E$. coli, Klebsiella spp. and Acinetobacter spp. by biochemical tests and 16S rDNA sequencing. All these isolates showed high antibacterial resistance against Amoxacilin (64\%) and most of them showed

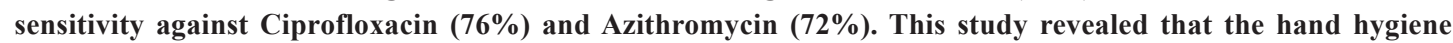
of street vendors is very poor and may have serious implications for public health due to possible contamination of food. This study, therefore, suggests proper training and education of street food vendors in order to improve their knowledge of personal hygiene and sanitation.
\end{abstract}

Keywords: Foodborne-pathogens, public health risks, antibiotic-resistance, street food contaminations

\section{Introduction}

Foodborne diseases are considered as a major global public health problem ${ }^{1}$.Over the years many food-borne diseases have been reported due to contaminated non-homemade food consumption ${ }^{2}$. Among various food types, street foods, which are very popular, are causing serious public health threats in many countries especially in developing countries. With the growing popularity of street foods, prevalence of pathogenic bacteria in street foods and water has been reported in many countries $^{3}$. The hands of ready-to-eat food service employees have been shown to be vectors in the spread of foodborne diseases in many countries, mainly because of poor personal hygiene $e^{4}$. It is also stated that unhealthy food handling practices contributed to approximately $97 \%$ of foodborne illnesses in food service establishments and homes ${ }^{3}$. Globally, statistical evidence indicates, food poisoning caused by the catering industry is $70 \%$ higher than that caused by any other sector ${ }^{5}$.

The prevalence of enteric pathogens like E coli, Shigella spp. and Salmonella enterica, the well known etiologic agents of diarrheal diseases, has been very high in Bangladesh for decades ${ }^{6,7}$. Because of the climatic conditions and poor hygiene, the loads of pathogenic bacteria have been reported in household drinking water and salads as well as foods. Antimicrobial resistance among enteropathogens, including $E$. coli has been reported to be increasing in recent years ${ }^{8}$, sometimes leading to point-break situations where no antibiotic treatment options remain ${ }^{9}$. These situations are of serious concern in developing countries where enteropathogens are frequently encountered and cause life-threatening infections, especially among children. Street foods are prepared in open space with visually dirty surroundings and the people handling the foods lack the knowledge of good personal hygiene. One of the major contributors of such foodborne enteric pathogens might be the person involved in preparation and serving of food. Hence, we, for the first time carried out this study to assess the loads of enteric pathogens and their antibiotic resistance patterns in the hands of street food vendors.

\section{Materials and Methods}

Sample collection and preparation

A total of 20 street food vendors were selected randomly from various parts of Dhaka University campus and nearby area. Various kinds of street food vendors were selected depending on the types of foods they prepare including, Fuchka $(\mathrm{n}=5)$, chotpoti $(n=5)$, salads $(n=5)$ and tea sellers $(n=5)$. The persons were informed verbally about the purpose of the study and immediately after their verbal agreement, the street food vendors rinsed their hands thoroughly in $500 \mathrm{~mL}$ sterile normal saline $(0.90 \% \mathrm{w} / \mathrm{v}$ of $\mathrm{NaCl})$, and the rinsed normal saline was then

*Corresponding author:

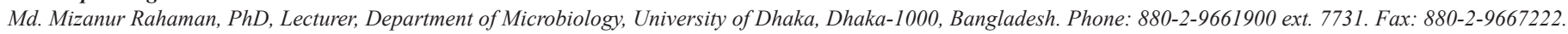
Email: razu002@gmail.com 
collected in labeled sterile plastic bags and brought in laboratory immediately for sample processing. After bringing the samples in the laboratory, $100 \mathrm{~mL}$ from each sample were centrifuged (Eppendorf, USA) at $11000 \mathrm{rpm}$ for 10 minutes at room temperature. After centrifugation, carefully $98 \mathrm{~mL}$ of the supernatant was removed and the remaining $2 \mathrm{~mL}$ of the concentrated fraction was used for various bacterial counts and isolations. For all the counting, two 10 -fold serial dilutions were performed twice before spreading on different culture medium.

\section{Total bacterial counts}

The total viable bacterial count was carried out by spread plate technique using Plate Count Agar (PCA) (Oxoid, UK) medium. $100 \mu \mathrm{L}$ of the concentrated sample and of each dilution were finely spread onto PCA and incubated at $37^{\circ} \mathrm{C}$ for $18-24$ hours and actual numbers of bacteria were estimated as colony forming unit $(\mathrm{CFU}) / \mathrm{mL}$ of hand rinse. Similarly, total coliforms and total fecal coliforms were counted using MacConkey agar and $\mathrm{mFC}$ agar medium (incubated at $37^{\circ} \mathrm{C}$ and $44.5^{\circ} \mathrm{C}$ for $18-24$ hours) respectively.

\section{Isolation of enteric bacteria}

Enteric bacteria were isolated from the MacConkey agar medium and sub-cultured to get pure cultures. Different selective and differential media like Eosine Methylene Blue (EMB) agar and MacConkey (MAC) agar were used to differentiate among different enteric bacteria. One set of all bacterial isolates were stocked in $20 \%$ glycerol and stored at $-80^{\circ} \mathrm{C}$.

\section{Presumptive identification of the enteric bacteria}

According to the methods described in the "Manual of Methods for General Bacteriology (American Society for Microbiology (ASM), 1981)", the isolates were presumptively identified based on their colony morphology, Gram staining and biochemical properties. Standard biochemical tests included Triple Sugar Iron (TSI), Motility Indole Urease (MIU), Methyl-Red (MR), VogesProskauer (VP), Citrate Utilization, Catalase test and Oxidase tests. All the experiments were performed in triplicate and the results were reproducible.

\section{Amplified ribosomal DNA restriction analysis}

ARDRA (Amplified ribosomal DNA restriction analysis) grouping of 16S rRNA gene amplicons amplified using 27F (52 -AGAGTTTGATCMATGGCTCAG-32 ) and 1492R (52 GGTTACCTTGTTACGACTT-32 $)^{10}$ primers were accomplished to verify the identity of the isolates ${ }^{11,12}$. For PCR, boiled DNA was prepared by boiling the bacterial suspension for 10 minutes at $100^{\circ} \mathrm{C}$ according to the previously discussed method ${ }^{13}$. The conditions of thermal cycler (Eppendorf Mastercycler ${ }^{\circledR}$, Germany) for amplification of $16 \mathrm{~S}$ rRNA gene were: initial denaturation of 5 min at $95^{\circ} \mathrm{C}$ followed by 30 cycles of denaturation of $45 \mathrm{~s}$ at $94^{\circ} \mathrm{C}$, annealing of $45 \mathrm{~s}$ at $58^{\circ} \mathrm{C}$, extension of $2.5 \mathrm{~min}$ at $72^{\circ} \mathrm{C}$ with a final extension of $10 \mathrm{~min}$ at $72^{\circ} \mathrm{C}$. AluI (Thermo Fisher Scientific, USA) restriction enzyme was used for the digestion of 16s rRNA gene amplicons. The digestion products were resolved by agarose gel electrophoresis using $1.5 \%$ agarose $(\mathrm{w} / \mathrm{v})$ gel running for 90 minutes at $70 \mathrm{~V}$ and the gel was observed using Alpha Imager HP Gel-documentation system (Cell bioscience, USA). Genetically related isolates were clustered together based on the restriction patterns using the tool Phoretix 1D (Totallab, UK). In this experiment, there were three experimental controls- uncut experimental DNA, digestion of commercially supplied control DNA and no-enzyme "mock" digestion. Two different size markers, $1 \mathrm{~kb}$ (Promega, USA) and $100 \mathrm{bp}$ (Promega, USA) DNA ladders, were used to analyze different restriction fragments.

\section{S rDNA sequencing}

16S rRNA gene amplicons of selected isolates representative of each genotype were sequenced followed by phylogenetic analysis to find out their close relatives. Amplified PCR products were purified by Wizard PCR SV Gel and PCR Clean-Up System kit (Promega, USA) according to the manufacturer's instructions for sequencing purpose. The purified PCR products were sequenced by automated cycle sequencing from DNA sequencing lab of First BASE Laboratories SdnBhd, Malaysia. Partial sequences, obtained using forward and reverse primers, were combined to full length sequences via the SeqMan Genome Assembler ${ }^{14}$ and aligned, checked and processed by using Molecular Evolutionary Genetics Analysis (MEGA) version $6.0^{15}$, an integrated tool for sequence analysis. Phylogenetic and molecular evolutionary analyses were also conducted using the MEGA version 6.0 software package. The multiple sequence alignment of the retrieved reference sequences from NCBI, EMBL or DDBJ and sequences of representative isolates was performed with the ClustalW program embedded in Mega 6 . Aligned sequences were refined by sequence trimming and conserved region identification. Refined sequences were used for selecting best model and phylogenetic tree construction using the Neighbor-Joining Algorithm and selecting 1000 bootstrap replication.

\section{Antimicrobial susceptibility tests}

Susceptibility to antimicrobials was determined by an agar diffusion test using antimicrobial agents impregnated paper discs (Oxoid, USA) as described by the Clinical Laboratory Standards Institute (CLSI) guidelines ${ }^{16}$. The antibiotics used in this study were Ampicillin (AML $10 \mu \mathrm{g}$ ), ciprofloxacin (CIP, $5 \mu \mathrm{g}$ ), trimethoprim-sulfamethoxazole (SXT, $25 \mu \mathrm{g}$ ), gentamicin (GN, $10 \mu \mathrm{g}$ ) and Azithromycin (AZM, $5 \mu \mathrm{g}$ ). E. coli ATCC 25922 and Staphylococcus aureus ATCC 25923 were used as negative and positive controls, respectively. The diameter of the zone of inhibition were used to interpret the results according to the guidelines ${ }^{16}$.

\section{Results}

\section{Total bacterial counts}

For each sample, total viable counts, total coliform counts and total fecal coliform counts were performed. All the samples showed very high counts after 18-24 hours incubation as shown in Table 1. 
Table 1. Total bacterial counts in the hand rinse samples

\begin{tabular}{|c|c|c|c|c|}
\hline Vendor type & Samples & Total viable counts $(\mathrm{cfu} / \mathrm{mL})$ & Total coliform $(\mathrm{cfu} / \mathrm{mL})$ & Total fecal coliform $(\mathrm{cfu} / \mathrm{mL})$ \\
\hline \multirow[t]{4}{*}{$\overline{\text { Tea }}$} & 1 & $2.3 \times 10^{6}$ & $2.5 \times 10^{4}$ & $2.0 \times 10^{4}$ \\
\hline & 2 & $5.7 \times 10^{5}$ & $3.6 \times 10^{4}$ & $2.6 \times 10^{4}$ \\
\hline & 4 & $2.6 \times 10^{6}$ & $6.1 \times 10^{4}$ & $2.8 \times 10^{4}$ \\
\hline & 5 & $2.5 \times 10^{6}$ & $9.6 \times 10^{4}$ & $1.7 \times 10^{4}$ \\
\hline & 3 & $3.7 \times 10^{6}$ & $6.1 \times 10^{5}$ & $6.1 \times 10^{4}$ \\
\hline & 4 & $3.5 \times 10^{5}$ & $1.0 \times 10^{4}$ & $5.3 \times 10^{3}$ \\
\hline & 5 & $8.5 \times 10^{5}$ & $4.1 \times 10^{4}$ & $2.7 \times 10^{3}$ \\
\hline \multirow[t]{2}{*}{ Chotpoti } & 1 & $6.1 \times 10^{6}$ & $1.2 \times 10^{5}$ & $3.4 \times 10^{4}$ \\
\hline & 5 & $7.8 \times 10^{5}$ & $5.6 \times 10^{4}$ & $1.7 \times 10^{4}$ \\
\hline \multirow[t]{5}{*}{ Salad } & 1 & $1.3 \times 10^{5}$ & $9.5 \times 10^{4}$ & $4.4 \times 10^{3}$ \\
\hline & 2 & $2.1 \times 10^{6}$ & $9.6 \times 10^{4}$ & $6.0 \times 10^{3}$ \\
\hline & 3 & $2.9 \times 10^{5}$ & $4.1 \times 10^{3}$ & $4.5 \times 10^{3}$ \\
\hline & 4 & $3.4 \times 10^{5}$ & $3.0 \times 10^{4}$ & $1.7 \times 10^{4}$ \\
\hline & 5 & $3.9 \times 10^{5}$ & $5.1 \times 10^{4}$ & $1.9 \times 10^{4}$ \\
\hline
\end{tabular}

\section{Bacterial isolates}

A total of 25 enteric bacteria were isolated from the samples based on the cultural characteristics on MacConkey agar medium and mFC medium (Table 2). All the 25 isolates were stored at $-20^{\circ} \mathrm{C}$ before further analysis.

Table 2. Classification of the isolates in different morphgroups based on their culture

\begin{tabular}{|c|c|c|c|c|c|c|c|c|c|c|c|}
\hline \multirow[b]{2}{*}{ Source } & \multirow{2}{*}{ 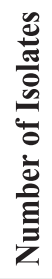 } & \multicolumn{7}{|c|}{$\begin{array}{l}\text { Growth Characteristics on Different Differential and } \\
\text { Selective Media }\end{array}$} & \multicolumn{3}{|c|}{$\begin{array}{l}\text { Microscopic } \\
\text { Characteristics }\end{array}$} \\
\hline & & $\underbrace{\frac{\pi}{3}}$ & 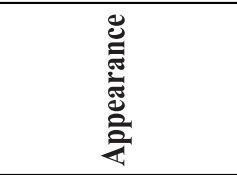 & פ & 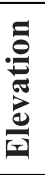 & 苞 & 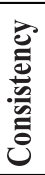 & 当 & $\stackrel{\mathbb{n}}{-\infty}$ & 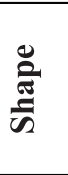 & 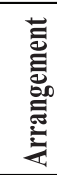 \\
\hline \multirow{6}{*}{$\begin{array}{l}\text { Hand } \\
\text { rinse }\end{array}$} & \multirow[b]{2}{*}{16} & MAC & Dark pink & $\mathrm{C}$ & $\mathrm{F}$ & $\mathrm{E}$ & $\mathrm{D}$ & \multirow{2}{*}{ 光 } & \multirow[b]{2}{*}{$\mathrm{S}$} & \multirow[b]{2}{*}{ SR } & \multirow{2}{*}{$\begin{array}{l}\stackrel{0}{\infty 0} \\
\stackrel{\tilde{D}}{\Xi}\end{array}$} \\
\hline & & EMB & $\begin{array}{l}\text { Blue black with } \\
\text { GMS }\end{array}$ & $\mathrm{C}$ & $\mathrm{F}$ & $\mathrm{E}$ & $\mathrm{D}$ & & & & \\
\hline & \multirow[b]{2}{*}{8} & MAC & Light pink & $\mathrm{C}$ & $\mathrm{R}$ & $E$ & $\mathrm{G}$ & \multirow[b]{2}{*}{ 息 } & \multirow[b]{2}{*}{ M } & \multirow[b]{2}{*}{$\mathrm{R}$} & \multirow[b]{2}{*}{$\begin{array}{l}\frac{0}{00} \\
\stackrel{\Xi}{\Xi}\end{array}$} \\
\hline & & EMB & $\begin{array}{l}\text { Brown, dark } \\
\text { centered }\end{array}$ & $\mathrm{C}$ & $\mathrm{R}$ & $\mathrm{E}$ & G & & & & \\
\hline & \multirow[b]{2}{*}{1} & $\mathrm{MAC}$ & Purple & $\mathrm{C}$ & $\mathrm{R}$ & $E$ & $\mathrm{G}$ & \multirow[b]{2}{*}{ 尝 } & \multirow[b]{2}{*}{$\mathrm{S}$} & \multirow[b]{2}{*}{ SR } & \multirow[b]{2}{*}{$\underset{\infty}{\stackrel{0}{\leftrightarrows}}$} \\
\hline & & EMB & Blue & $\mathrm{C}$ & $\mathrm{R}$ & $\mathrm{E}$ & G & & & & \\
\hline
\end{tabular}




\section{Presumptive identification of the isolates}

Based on the colony characteristics on different selective and differential media, 3 morphological groups were found. The isolates were all Gram-negative and further analyzed by different biochemical tests such as Kligler's Iron Agar (KIA) test, MotilityIndole-Urease (MIU), IMViC (Indole, Methyl-red (MR), VogesProskauer (VP), Citrate, Oxidase test and catalase tests. The outcome of the tests was used to presumptively identify the isolates. It was presumed that 16 of the isolates belonged to the Genus Escherichia, 8 of the isolates belonged to the genus Klebsiella and 1 isolate belonged to the genus Acinetobacter (Table 3).

Genotyping by Amplified Ribosomal DNA Restriction Analysis

25 isolates belonging to 3 different phenotypic groups (based on morphological and biochemical characteristics) were clustered into individual genotypes by Amplified Ribosomal DNA Restriction Analysis (ARDRA). There was a good correlation between the phenotypic groups and ARDRA genotypes where 3 genotypic patterns were revealed by completely digesting $16 \mathrm{~S}$ rRNA gene amplicons using AluI (Figure $1 \& 2$ ).

\section{Phylogenetic analysis}

16S rDNA sequencing was carried out and phylogenetic and molecular evolutionary analysis revealed that all three matched with the biochemical identification results as Klebsiella spp., Acinetobacter spp. and E. coli respectively as shown in Figure 3.

\section{Antibacterial resistance}

Antibacterial resistance analysis of all the isolated strains revealed that most of the isolates are resistant to amoxicillin (64\%), while most of them are sensitive to ciprofloxacin $(76 \%)$, azithromycin $(72 \%)$, sulfamethoxazol $(84 \%)$ and gentamycin $(56 \%)$ respectively (Figure 4$)$.

Table 3. Biochemical test results of the 3 ARDRA groups

\begin{tabular}{|c|c|c|c|c|c|c|c|c|c|c|c|c|}
\hline \multicolumn{4}{|c|}{ KIA } & \multirow[t]{2}{*}{ Motility } & \multirow[t]{2}{*}{ Indole } & \multirow{2}{*}{$\begin{array}{l}\text { Urease } \\
\text { activity }\end{array}$} & \multirow[t]{2}{*}{ MR } & \multirow[t]{2}{*}{ VP } & \multirow[t]{2}{*}{ Citrate } & \multirow{2}{*}{$\begin{array}{c}\text { Oxidase } \\
\text { test }\end{array}$} & \multirow{2}{*}{$\begin{array}{c}\text { Catalase } \\
\text { test }\end{array}$} & \multirow{2}{*}{$\begin{array}{c}\text { Presumptive } \\
\text { organism }\end{array}$} \\
\hline Slant & Butt & Gas & $\mathrm{H}_{2} \mathrm{~S}$ & & & & & & & & & \\
\hline $\mathrm{A}$ & $\bar{A}$ & - & - & - & - & + & - & - & - & + & - & Klebsiella spp. \\
\hline A & A & + & - & - & - & + & - & + & + & + & - & Acinetobacter spp. \\
\hline K & A & + & - & + & + & - & + & - & + & - & - & Escherichia spp. \\
\hline
\end{tabular}

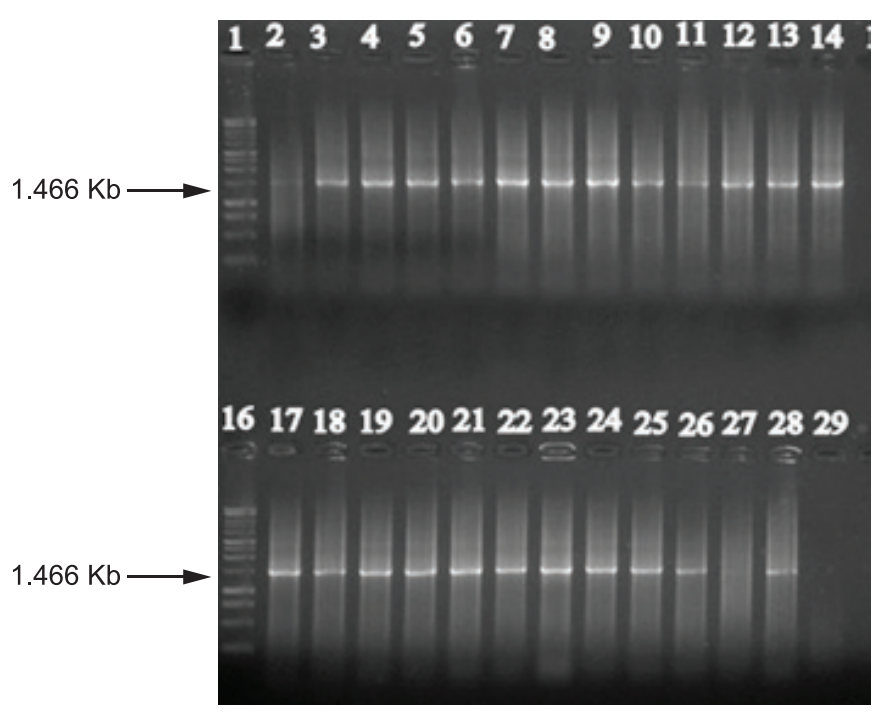

Figure 1. Amplicons of $16 \mathrm{~S}$ rRNA genes [Lane 1, 16Molecular Marker (1Kb), Lane 2-14, 17-28-contain approximately $1.5 \mathrm{~Kb}$ band, Lane 29-Negative control].The $1 \mathrm{kp}$ ladder was originated from Promega, USA
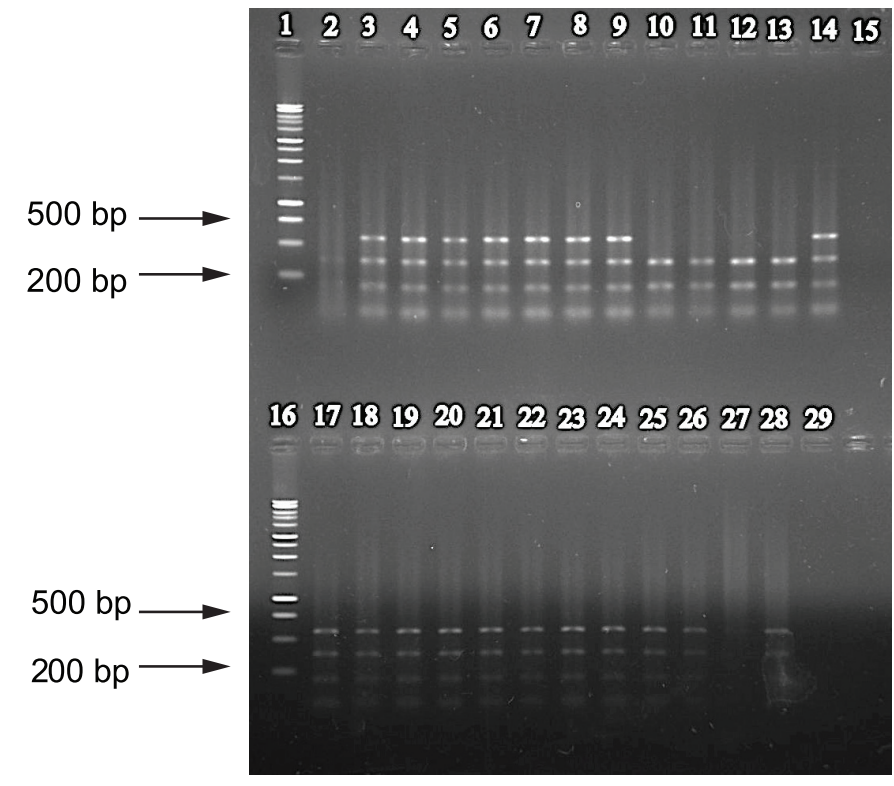

Figure 2. ARDRA pattern of 25 isolates using Alu1 restriction enzyme 





molecular techniques like ARDRA is used now a days to reduce the huge workloads like conventional biochemical tests for each strains and probably expensive serological tests. By performing ARDRA using Alu1 restriction enzyme, we observed 3 different patterns from all the isolates. Following this, conventional biochemical tests confirmed the 3 different groups as Klebsiella spp., Acinetobacter spp. and E. coli. The 16S rDNA sequencing and phylogenetic analysis further confirmed the identification of the bacteria. Antibacterial resistance assay was performed to analyze the susceptibility of the isolated enteric bacteria to the commonly used antibiotics as antibiotic resistance is found very often from the isolates in Bangladesh and neighboring countries $6,7,18,19$. Very high resistance was observed with amoxicillin and interestingly, there was high susceptibility to other antibiotics. This might be related to the usage and price of the antibiotics. Among the low-income people, the most commonly used antibiotic is amoxicillin. However, further studies with different economic status might explain these resistance patterns better.

This study successfully isolated and identified 3 types of pathogenic enteric bacteria from hand rinse of street food vendors. The overall result of this study is putting a huge threat to the public health of Bangladesh as people are becoming more interested in street foods. The personal hygiene is too poor of these vendors and they clearly lack the knowledge of food safety. The future studies can be carried out to regularly monitor the prevalence of the enteric pathogens from street foods as well as foods from different restaurants and hospitals. All these enteric bacteria can further be well characterized to study their toxigenicity and other pathogenic roles to aware people about such situations. Strict guidelines and proper authorization is required to overcome such situation. Government authorities like food safety authority and related organizations can regularly monitor and take measures to train such food handlers for the protection of public health.

\section{Acknowledgement:}

We thank Professor Dr. Sabita Rezwana Rahman, Professor Dr. Chowdhury Rafiqul Ahsan and Professor Dr. Anwar Hossain for their kind support with the lab space and instruments. We also thank Mr. Shamsur Rahman and Mr. Rafiqul Islam for their technical assistance throughout the project. There is no conflict of interests among the authors.

\section{Reference}

1. Todd E. 2014. Foodborne diseases: Overview of biological hazards and foodborne diseases.

2. Anderson P and Stone DM. 1955. Staphylococcal food poisoning associated with spray-dried milk. J Hygiene.53:387-97.

3. Howes M, McEwen S, Griffiths M and Harris L. 1996. Food handler certification by home study: Measuring changes in knowledge and behavior.Dairy, food and environmental sanitation: a publication of the International Association of Milk, Food and Environmental Sanitarians (USA). 16:737-44.

4. Lues J and Van Tonder I. 2007. The occurrence of indicator bacteria on hands and aprons of food handlers in the delicatessen sections of a retail group. Food cont. 18:326-32.

5. Wilson M, Murray AE, Black MA and McDowell DA.1997. The implementation of hazard analysis and critical control points in hospital catering. Managing Service Quality: An International Journal. 7:150-6.

6. Nawas T, Mazumdar R and Das S. 2012. Microbiological quality and antibiogram of E. coli, Salmonella and Vibrio of salad and water from restaurants of Chittagong. J Env Sci Nat Res.5:159-66.

7. Talukdar PK, Rahaman M, Rahman M, Nabi A, Islam Z, Hoque MM, Endtz HP and Islam MA. 2013. Antimicrobial resistance, virulence factors and genetic diversity of Escherichia coli isolates from household water supply in Dhaka, Bangladesh. PloS one. 8:e61090.

8. Pitout JD, Laupland KB. 2008. Extended-spectrum $\beta$ lactamaseproducing Enterobacteriaceae: an emerging public-health concern. The Lanc infec dis. 8:159-66.

9. Lynch III JP, Clark NM and Zhanel GG. 2013. Evolution of antimicrobial resistance among Enterobacteriaceae (focus on extended spectrum $\beta$ lactamases and carbapenemases). Exp opin pharmaco. 14: 199-210.

10. Lane D. 1991.16S/23S rRNA sequencing. Nucleic acid techniques in bacterial systematics.125-75.

11. Vaneechoutte M, Rossau R and De Vos P. 1992. Rapid identification of bacteria of the Comamonadaceae with amplified ribosomal DNA-restriction analysis (ARDRA). FEMS Microbiol Let. 93:227-33.

12. Heyndrickx M, Vauterin L, Vandamme P, Kersters K andDe Vos P. 1996. Applicability of combined amplified ribosomal DNA restriction analysis (ARDRA) patterns in bacterial phylogeny and taxonomy. J Microbiol Met. 26:247-59.

13. Queipo-Ortuño MI, Colmenero JDD, Macias M, Bravo MJ and Morata P. 2008. Preparation of bacterial DNA template by boiling and effect of immunoglobulin $\mathrm{G}$ as an inhibitor in real-time PCR for serum samples from patients with brucellosis. Clin Vac Immunol. 15:293-6.

14. Swindell SR and Plasterer TN. 1997. SEQMAN. Sequence data analysis guidebook. 75-89.

15. Tamura K, Stecher G, Peterson D, Filipski A and Kumar S. 2013. MEGA6: molecular evolutionary genetics analysis version 6.0. Mol Biol Evol. 30:2725-9.

16. Cockerill FR. 2011. Performance standards for antimicrobial susceptibility testing: twenty-first informational supplement: Clinical and Laboratory Standards Institute (CLSI).

17. Islam S, Begum HA and Nili NY. 2010. Bacteriological safety assessment of municipal tap water and quality of bottle water in Dhaka City: Health hazard analysis. Bang J Med Microbiol. 4:9-13.

18. Ram S, Vajpayee P, Tripathi U, Singh R, Seth P and Shanker R. 2008. Determination of antimicrobial resistance and virulence gene signatures in surface water isolates of Escherichia coli. J App Microbiol. 105:1899-908.

19. Fain AR. 1996. A review of the microbiological safety of fresh salads. Dairy, food and environmental sanitation: a publication of the International Association of Milk, Food and Environmental Sanitarians (USA). 